\title{
Ramophialophora chlamydospora, a new species from an alkaline lake of Wadi-El-Natron, Egypt
}

\author{
Moubasher AH ${ }^{1,2}$, Ismail MA ${ }^{1,2}$, Al-Bedak $\mathrm{OA}^{2^{*}}$ and Mohamed RA ${ }^{1}$ \\ ${ }^{1}$ Department of Botany and Microbiology, Faculty of Science, Assiut University, Assiut, Egypt \\ ${ }^{2}$ Assiut University Mycological Centre (AUMC), Assiut University, Assiut, Egypt
}

Moubasher AH, Ismail MA, Al-Bedak OA, Mohamed RA 2019-Ramophialophora chlamydospora, a new species from an alkaline lake of Wadi-El-Natron, Egypt. Asian Journal of Mycology 2(1), 110-117, Doi 10.5943/ajom/2/1/5

\begin{abstract}
Ramophialophora chlamydospora, a dematiaceous hyphomycete, recovered from alkaline water of Lake Fasida in Wadi-El-Natron, Egypt, is described. It has phenotypic characterization of branched conidiophores ending with terminal phialides with collarettes, on which dacryoid, brown conidia are formed in slimy heads, and the formation of abundant chlamydospores, a characteristic morphological feature for this new species, that differentiates this new species from the other four species of Ramophialophora. Sequence analysis of ITS region revealed its relationship with members of order Sordariales. A culture of the new fungus was preserved as pure one and deposited in the culture collection of the Assiut University Mycological Centre as AUMC 11013. The ITS sequence data was uploaded to the GenBank as KX446768 and the morphological characterization was uploaded to MycoBank as MB828700.
\end{abstract}

Key words - Alkaline lakes - Phylogeny - Ramophialophora - Sordariales - Wadi-El-Natron

\section{Introduction}

Wadi-El-Natron depression in Egypt has twenty saline lakes which dry up in summer and become hypersaline and rich with natron, a mixture of sodium salts (Lucas and Harris 1962). Lake Fasida is a small and shallow basin which dries up completely during the summer resulting in the formation of thick deposits of salts on its bottom (Shortland et al. 2011). During surveys and isolation of extremophilic fungi from hypersaline, alkaline lakes of Wadi-El-Natron, Egypt (Al-Bedak 2017; Ismail et al. 2017), an interesting strain was recovered on $1 \%$ glucose-Czapek's agar at $25{ }^{\circ} \mathrm{C}$, from water of Lake Fasida and it showed a strong relationship to genus Ramophialophora.

The genus Ramophialophora is a dematiaceous hyphomycete which has phialides with collarettes and its conidia are formed in glutinous masses. In addition, branched conidiophore in some species of that genus, is a characteristic morphological feature that never described in Phialophora or any other similar genera (Calduch et al. 2004). Up to now, only four species of Ramophialophora were described; the type species $R$. vesiculosa (Calduch et al. 2004) isolated from forest soil sample in Asturias Province, Spain; $R$. humicola (Madrid et al. 2010) from a soil sample collected from Ronda, Spain and $R$. globispora from plant debris and $R$. petraea from rock sample in Karst caves in China (Zhang et al. 2017). 


\section{Materials and methods}

\section{Sampling site}

Wadi-El-Natron is situated between $30^{\circ} 17^{\prime}$ and $30^{\circ} 38^{\prime} \mathrm{N}$ and $30^{\circ} 2^{\prime}$ and $30^{\circ} 30^{\prime} \mathrm{E}$ in the Western Desert adjacent to the Nile Delta, Egypt, below the sea level by $23 \mathrm{~m}$ and below the water level of Rosetta branch of the Nile river by $38 \mathrm{~m}$ (Abd-el-Malek and Rizk 1963). Water samples were collected from Lake Fasida during Feb 2012 (Ismail et al. 2017) and their pH, total dissolve solids (TDS), carbonates and bicarbonates were determined.

\section{Strain isolation}

The fungus was recovered on $1 \%$ glucose-Czapek's agar from water of Fasida lake using pourplate technique (Sanders 2012). The medium has the following composition $(\mathrm{g} / \mathrm{L})$ : glucose, 10; $\mathrm{Na}_{2} \mathrm{NO}_{3}, 2 ; \mathrm{K}_{2} \mathrm{HPO}_{4}, 1 ; \mathrm{KCl}, 0.5 ; \mathrm{MgSO}_{4} .7 \mathrm{H}_{2} \mathrm{O}, 0.5 ; \mathrm{FeSO}_{4}, 0.01 ; \mathrm{ZnSO}_{4}, 0.01 ; \mathrm{CuSO}_{4}, 0.005$, agar, 15; Rose Bengal, 0.05 and chloramphenicol, 0.25 and the $\mathrm{pH}$ was adjusted at 7.3. The dishes were incubated for 7-15 days at $25^{\circ} \mathrm{C}$. The developed colony of the new fungus was purified and preserved on PDA slants at $4{ }^{\circ} \mathrm{C}$ as pure culture.

\section{Morphological studies}

Cultural morphology and growth rates were studied on Czapek's Dox agar $(\mathrm{Cz})$, potato dextrose agar (PDA), malt extract agar (MEA), oat agar (OA), corn meal agar (CMA), $\mathrm{Cz}$ supplemented with $1 \%, 2 \%, 3 \%, 4 \%$ and $5 \% \mathrm{NaCl}$ and $\mathrm{Cz}$ with pHs of 6, 7, 8, 9 and 10. The inoculated plates were incubated at $25^{\circ} \mathrm{C}$ for 7 days in case of $\mathrm{Cz}+\mathrm{NaCl}$ concentrations and $\mathrm{Cz}$ with different $\mathrm{pHs}$, and 14 days in case of $\mathrm{Cz}$, PDA, MEA, OA and CMA. Microscopic features on PDA were examined in lacto-phenol cotton blue.

\section{Molecular identification}

\section{DNA extraction}

$0.2 \mathrm{~g}$ of 7-day-old fungal mycelia of Ramophialophora chlamydospora grown on PDA, were grounded and transferred to $1.5-\mathrm{ml}$ microfuge tubes. $800 \mu \mathrm{l} \mathrm{CTAB}$ buffer composed of $3 \% \mathrm{CTAB}$, $1.4 \mathrm{M} \mathrm{NaCl}, 0.2 \%$ Mercaptoethanol, $20 \mathrm{mM}$ EDTA, $100 \mathrm{mM}$ TRIS-HCl pH 8.0 and $1 \% \mathrm{PVP}-40$, were added to each tube. After incubation at $65^{\circ} \mathrm{C}$ for $30 \mathrm{~min}, 800 \mu \mathrm{l}$ of CI Mix with the composition of $24 \mathrm{ml}$ chloroform and $1 \mathrm{ml}$ isoamyl alcohol, were gently added and mixed with the tube contents. A clear supernatant was obtained by centrifugation at $10000 \mathrm{xg}$ for $10 \mathrm{~min}$. For DNA precipitation $2 / 3$ volume of isopropanol (precooled at $-20^{\circ} \mathrm{C}$ ) was added and mixed gently. The samples were incubated at $4{ }^{\circ} \mathrm{C}$ overnight, thereafter centrifugation at $13000 \mathrm{xg}$ for $10 \mathrm{~min}$. The supernatant was discarded and the pellet was pooled and washed with $200 \mu \mathrm{l}$ washing buffer composed of $76 \%$ ethanol and $10 \mathrm{mM}$ ammonium acetate. The washing buffer was carefully decanted and the pellet was suspended in $200 \mu \mathrm{TE}$ buffer supplemented with $10 \mathrm{mg} / \mathrm{ml}$ RNase. After incubation at $37{ }^{\circ} \mathrm{C}$ for $30 \mathrm{~min}, 100 \mu \mathrm{l}$ of $7.5 \mathrm{M}$ ammonium acetate and $750 \mu \mathrm{l}$ ethanol were added and mixed gently. Samples were centrifuged at $13000 \mathrm{xg}$ for $10 \mathrm{~min}$ at room temperature. The supernatant was completely discarded and the pellet was suspended in $100 \mu \mathrm{l}$ sterile distilled water.

\section{PCR for rDNA and sequencing using ITS1 and ITS4 primers}

The PCR reaction was performed using SolGent EF-Taq. The universal primers ITS1 and ITS4 (White et al. 1990) were used. In the PCR tubes $1 \mu 1$ of DNA template, $1 \mu 12.5 \mathrm{mM}$ dNTP mix, 0.2 unit of Taq polymerase, $5 \mu \mathrm{l}$ of $10 \mathrm{x}$ complete buffer and $40 \mu \mathrm{l}$ of sterile ddH2O, 10 pmol of ITS 1 (5' TCC GTA GGT GAA CCT TGC GG 3') and ITS4 (5' TCC TCC GCT TAT TGA TAT GC 3') were added. Then the PCR amplification was carried out using the following sequence: one round of amplification consisting of denaturation at $95{ }^{\circ} \mathrm{C}$ for $15 \mathrm{~min}$ followed by 30 cycles of denaturation at $95{ }^{\circ} \mathrm{C}$ for $20 \mathrm{sec}$, annealing at $50^{\circ} \mathrm{C}$ for $40 \mathrm{sec}$ and extension at $72{ }^{\circ} \mathrm{C}$ for $1 \mathrm{~min}$, with a final extension step of $72{ }^{\circ} \mathrm{C}$ for $5 \mathrm{~min}$. The PCR products were then purified with the SolGent PCR Purification 
Kit-Ultra (SolGent, Daejeon, South Korea) prior to sequencing. The purified PCR products were confirmed on $1 \%$ agarose gel by electrophoresis using size marker. The bands were eluted and sequenced in the forward and reverse directions.

\section{Phylogenetic analyses}

Sequence data for the representative type strains of all published Ramophialophora species were downloaded from GenBank. Sequences produced in this study and those from GenBank were aligned using ClustalX (Thompson et al. 1997) and optimized manually. Sequence alignments for all data sets were uploaded to TreeBASE http://purl.org/phylo/treebase/phylows/study/TB2:S23783 (study no. 23783), and sequence for the novel species was deposited in GenBank. Maximumparsimony (MP) and Maximum-likelihood (ML) phylogenetic analyses were performed using PAUP* 4.0 (Swofford 2001). Maximum-likelihood (ML) analysis (Felsenstein 1981) was carried out under these settings: heuristic searches with random stepwise addition of 100 replicates and TBR rearrangements. The best optimal model of nucleotide substitution for the ML analyses was determined using akaike information criterion (AIC) as implemented in Modeltest 3.7 (Posada and Crandall 1998). K81 was the best fit for the ITS dataset. Phylogenetic trees were visualized using Njplot (Perriere and Gouy 1996) and edited using Adobe Illustrator CS6.

\section{Results}

The water sample collected from Lake Fasida registered alkaline $\mathrm{pH}$ of 9.53, TDS $7.12 \%$ with high carbonates content of $40.8 \mathrm{~g} / \mathrm{L}$ and bicarbonates of $23.5 \mathrm{~g} / \mathrm{L}$.

\section{Phylogenetic analysis}

The ITS dataset comprised 23 sequences, of which 11 are Ramophialophora and the remaining sequences for related taxa belong to the order Sordariales (Fig. 1). The maximum parsimony dataset consisted of 557 characters with 254 characters as constant information, 63 characters as variable characters which were parsimony-uninformative, and 240 characters were counted as parsimonyinformative characters. Maximum Parsimony analyses resulted in two most parsimonious tree with a tree length of 793 steps, a consistency index of 0.6482 , a retention index of 0.7267 and a rescaled consistency index of 0.4711. Maximum likelihood analysis yielded one tree (-ln likelihood = 4700.430) (Fig. 1). The new species Ramophialophora chlamydospora consistently grouped with the four species of Ramophialophora along with Cercophora appalachianensis and Coronatomyces cubensis but with low weak support. However, Ramophialophora chlamydospora formed a highly supported clade (92\% ML/84 \% MP) with $R$. globispora, $R$. petraea and Cercophora appalachianensis (Fig. 1). Phylogenetic trees obtained from Maximum Parsimony yielded trees with similar overall topology with the one shown in Fig. 1.

\section{Taxonomy}

Ramophialophora chlamydospora AH Moubasher, MA Ismail, OA Al-Bedak \& RA Mohamed, sp. nov.

GenBank number: KX446768; MycoBank number: MB828700

Fig. 2

Typification: EGYPT. Wadi-El-Natron: Lake Fasida, from alkaline water sample, 2 Feb 2012, Osama A. Al-Bedak (holotype AUMC 11013).

Etymology - Referring to the formation of abundant chlamydospores.

\section{Cultural characteristics}

Colonies on PDA attaining $50 \mathrm{~mm}$ in 14 days at $25^{\circ} \mathrm{C}$, composed of immersed greyish-brown mycelium (9F3-4/10F3-4), and orange grey conidial tufts (5B2/6B2). Conidiophores erect, sinuous, cylindrical, septate, branched, brown to dark brown at the lower part, becoming paler towards the apex, smooth, thick-walled, $(-7) 12-20(-35) \times 2-3 \mu \mathrm{m}(\mathrm{n}=50)$. Conidiophore branches ending with phialides. Phialides monophialidic, smooth-walled, often waisted, sinuous, 15-20 $\times 2-4 \mu \mathrm{m}(\mathrm{n}=50)$ 
with conspicuous, collarettes, mostly $3-5 \mu \mathrm{m}$ wide. Sporulation abundant after 14 days of incubation. Conidia one-celled, subhyaline, brown, smooth-walled, dacryoid, mostly 2.5-3.5 (-4.0) $\times 2-3 \mu \mathrm{m}$ $(\mathrm{n}=50)$, often with a cylindrical hilum, aggregated in slimy masses. Chlamydospores abundant, produced from immersed mycelia, at first hyaline, later brownish, in chains, clustering with age (Fig. 2). Sexual state not observed within 60 days of culturing.

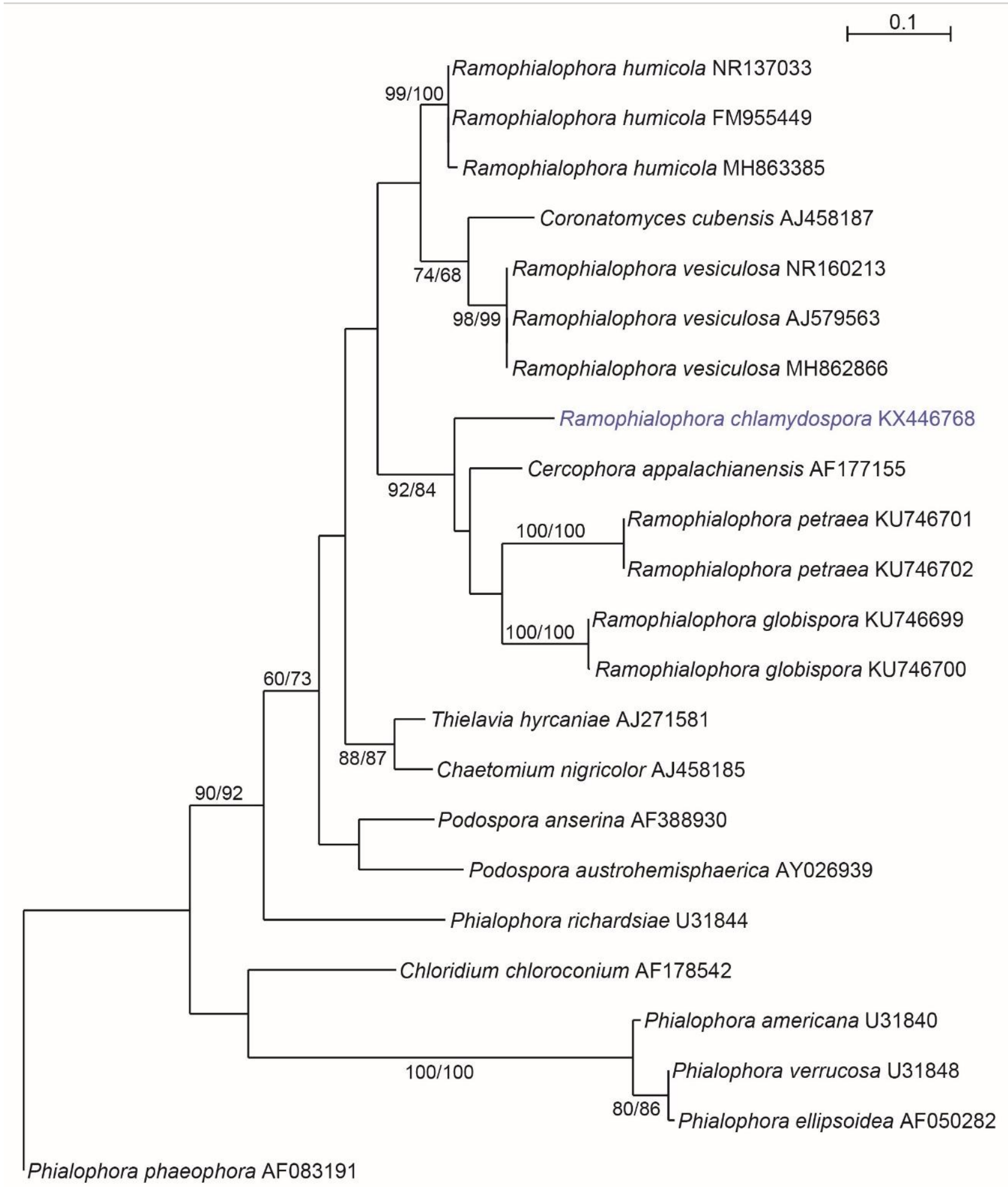

Fig. 1 - Maximum likelihood tree based on sequencing of the ITS regions of Ramophialophora chlamydospora AUMC 11013 with the most similar members of order Sordariales in GenBank. 
Colonies on $\mathrm{Cz}, \mathrm{OA}, \mathrm{CMA}$ and MEA attaining $40 \mathrm{~mm}, 60 \mathrm{~mm}, 60 \mathrm{~mm}$ and $30 \mathrm{~mm}$ in 14 days at $25{ }^{\circ} \mathrm{C}$. Sporulation sparse to rare on MEA, OA and CMA, moderate on $\mathrm{Cz}$ after 14 days of incubation. On $\mathrm{Cz}$ with different $\mathrm{pH}$ values of $6,7,8,9$ and 10 after 7 days of incubation at $25{ }^{\circ} \mathrm{C}$, colonies reaching $55 \mathrm{~mm}, 45 \mathrm{~mm}, 65 \mathrm{~mm}, 80 \mathrm{~mm}$ and $75 \mathrm{~mm}$ in diameter, respectively (Fig. 3) illustrating that the fungus is alkaliphilic. On $\mathrm{Cz}$ supplemented with $\mathrm{NaCl}$ with concentrations of 1 $\%, 2 \%, 3 \%, 4 \%$ and $5 \%$, colonies attaining $60 \mathrm{~mm}, 30 \mathrm{~mm}, 7 \mathrm{~mm}$ and $5 \mathrm{~mm}$, respectively, and it completely failed to grow on $5 \% \mathrm{NaCl}$ concentration (Fig. 3).
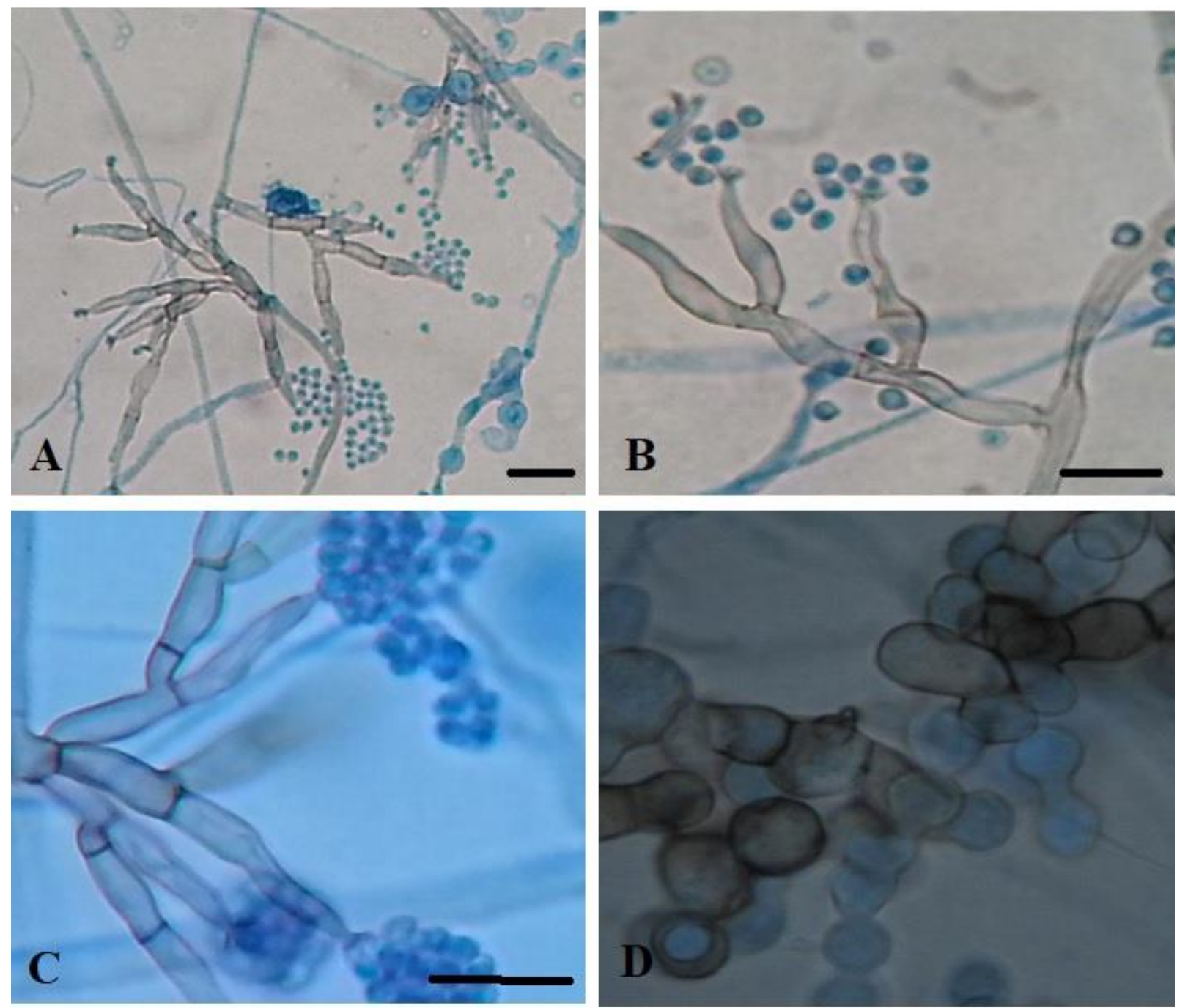

Fig. 2 - Morphological characters of Ramophialophora chlamydospora showing. A branched conidiophores. B phialides with flaring collarettes bearing dacryoid conidia. C branched conidiophores and slimy conidial heads on phialides. D chlamydospores. Scale Bars $=10 \mu \mathrm{m}$.

\section{Molecular study}

Sequence analysis of ITS region confirmed a closest relationship of the new species with the other members of Sordariales. The type strain was deposited in the culture collection of the Assiut University Mycological Centre (AUMC) as AUMC 11013 and the ITS sequence was uploaded to GenBank with accession number KX 446768. The percentage of sequence similarity to the closest matching taxa of Ramophialophora and other closer species of Sordariales did not exceed $92 \%$ revealing that the current species is a new taxon (Fig. 1).

\section{Discussion}

The morphological examination of $R$. chlamydospora showed some of the typical phenotypic features of Phialophora such as phialides with flaring collarettes on which conidia are formed in 
slimy heads, however, it distinguished from Phialophora species by its branching conidiophores. The novel species was isolated from alkaline water sample $(\mathrm{pH}=9.53)$ from Lake Fasida which contained high carbonates $(40.8 \mathrm{~g} / \mathrm{L})$ and bicarbonates $(23.5 \mathrm{~g} / \mathrm{L})$ contents. The novel species showed better growth on alkaline media with $\mathrm{pH}$ values of 9 and 10, indicating that the fungus is alkaliphile. Four species of Ramophialophora have been described up to date. These species are ecologically different from the new species since the habitat of $R$. chlamydospora is an alkaline water while $R$. vesiculosa (Calduch et al. 2004) and R. humicola (Madrid et al. 2010) were isolated from a soil sample in Spain, and $R$. globispora from plant debris and $R$. petraea from rock sample in Karst caves in China (Zhang et al. 2017). Our strain is the only species of that genus which isolated from an alkaline water sample. It resembles $R$. vesiculosa and $R$. humicola in the presence of branched conidiophores and dacryoid conidia and differs from them in the absence of vesicle at the end of conidiophores, but conidiophores of the new species terminated directly with phialides bearing conidia in slimy head. Ramophialophora chlamydospora is distinguished from $R$. globispora by its branched conidiophores and forming conidia in slimy heads whereas $R$. globispora is characterized by its unbranched conidiophores bearing tufty and terminally penicillate phialides and long macroscopic conidial beam formed with the aggregation of the conidial chains and its conidia are globose. Also, R. petraea differs from our isolate in the presence of reduced conidiophores and its phialides not abundant. The presence of chlamydospores in the new species is a characteristic feature, which differentiate it from all the known species of that genus. The differences between Ramophialophora species are illustrated in Table 1.
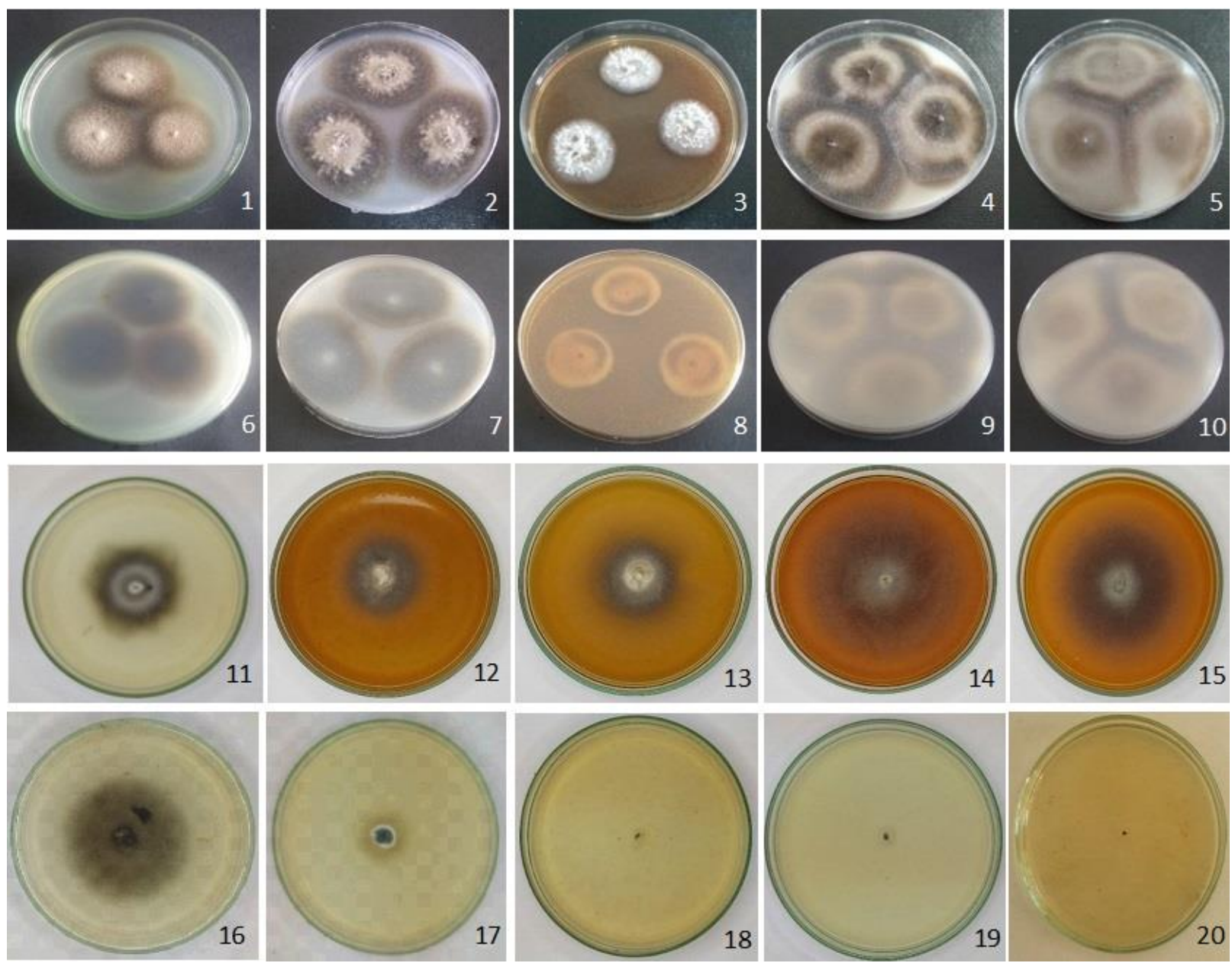

Fig. 3 - Growth of Ramophialophora chlamydospora at $25{ }^{\circ} \mathrm{C}$ on: 1 Czapek's Dox agar (Cz). 2 Potato dextrose agar (PDA). 3 Malt extract agar (MEA). 4 Oat agar (OA). 5 Corn meal agar (CMA). 6-10 reverse on the same media. $11-15 \mathrm{Cz}(\mathrm{pH} 6,7,8,9 \& 10) \cdot 16-20 \mathrm{Cz}+\mathrm{NaCl}(1 \%, 2 \%, 3 \%, 4$ $\% \& 5 \%)$. 
Table 1 Distinguishing characters of Ramophialophora species.

\begin{tabular}{|c|c|c|c|c|c|}
\hline $\begin{array}{l}\text { Ramophialophora } \\
\text { spp. }\end{array}$ & Conidiophores & Vesicles & Phialides & Conidia & Chlamydospores \\
\hline R. vesiculosa & Branched & Present & Simple & $\begin{array}{l}\text { Dacryoid, in slimy } \\
\text { heads }\end{array}$ & Absent \\
\hline R. humicola & Branched & Present & Simple & $\begin{array}{l}\text { Dacryoid, in slimy } \\
\text { heads }\end{array}$ & Absent \\
\hline R. globispora & Unbranched & Absent & Penicillate & Globose, in chains & Absent \\
\hline R. petraea & Reduced & Absent & Simple & $\begin{array}{l}\text { Globose, in slimy } \\
\text { heads }\end{array}$ & Absent \\
\hline R. chlamydospora & Branched & Absent & Simple & $\begin{array}{l}\text { Dacryoid, in slimy } \\
\text { heads }\end{array}$ & Abundant \\
\hline
\end{tabular}

\section{Key to known species of Ramophialophora}

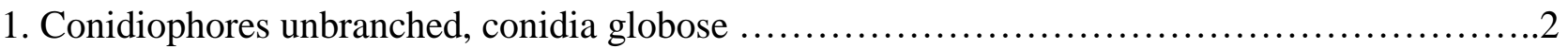

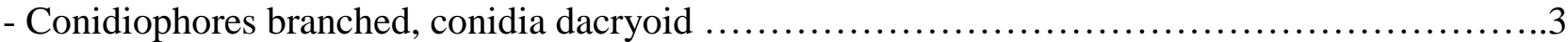

2. Phialides penicillate, inconspicuous collarette, conidia in chains ............................ globispora

- Phialides not abundant, ampulliform or sometimes irregular, conidia in slimy heads R. petraea

3. Chlamydospores abundant R. chlamydospora

- Chlamydospores absent R. vesiculosa

4. Vesicles, 3.5-6.5 $\mu \mathrm{m}$ at the broadest part, conidia $2.5-3 \mu \mathrm{m}$ R. humicola

- Vesicles, 1.5-4.0 $\mu \mathrm{m}$ at the broadest part, conidia $2.5-4.0 \mu \mathrm{m}$ 4

Acknowledgement

Professor M.A. Abdel-Wahab, Professor of Marine Mycology, Department of Botany and Microbiology, Faculty of Science, Sohag University, Sohag, Egypt is greatly appreciated and acknowledged for his kind help in phylogenetic analysis.

\section{References}

Abd-el-Malek Y, Rizk SG. 1963 - Bacterial sulphate reduction and the development of alkalinity. III. Experiments under natural conditions in the Wadi Natron. Journal of Applied Bacteriology, 26: 20-26.

Al-Bedak OA 2017 - Xylanases of some fungal species isolated from different habitats of Wadi-ElNatron-Egypt, Assiut University, Egypt.

Calduch M, Gené J, Stchigel AM, Cano JF, Guarro J. 2004 - Ramophialophora, a new anamorphic genus of Sordariales. Studies in Mycology 50, 83-88.

Felsenstein J. 1981 - Evolutionary trees from DNA sequences: a maximum likelihood approach. Journal of molecular evolution 17, 368-376.

Ismail MA, Moubasher AH, Mohamed RA, Al-Bedak OA. 2017 - Extremophilic fungi and chemical analysis of hypersaline, alkaline lakes of Wadi-El-Natron, Egypt. International Journal of Technical Research and Science 1, 345-363.

Lucas A, Harris JR. 1962 - Ancient Egyptian Materials and Industries: Edward Arnold, Dover Publications: London, UK.

Madrid H, Cano J, Stchigel A, Gené J, Guarro J. 2010 - Ramophialophora humicola and Fibulochlamys chilensis, two new microfungi from soil. Mycologia 102, 605-612.

Perriere G, Manolo G. 1996 - WWW-query: an on-line retrieval system for biological sequence banks. Biochimie 78, 364-369.

Posada D, Crandall KA. 1998 - Modeltest: testing the model of DNA substitution. Bioinformatics (Oxford, England) 14, 817-818. 
Sanders ER. 2012 - Aseptic laboratory techniques: plating methods. Journal of visualized experiments 63, 3064 .

Shortland AJ, Degryse P, Walton M, Geer M et al. 2011 - The evaporitic deposits of Lake Fazda (Wadi Natron, Egypt) and their use in Roman glass production. Archaeometry 53, 916-929.

Swofford DL. 2001 - Paup*: Phylogenetic analysis using parsimony (and other methods) 4.0. B5.

Thompson JD, Gibson TJ, Plewniak F, Jeanmougin F, Higgins DG. 1997 - The CLUSTAL_X windows interface: flexible strategies for multiple sequence alignment aided by quality analysis tools. Nucleic acids research 25, 4876-4882.

White TJ, Bruns T, Lee SJWT, Taylor JL. 1990 - Amplification and direct sequencing of fungal ribosomal RNA genes for phylogenetics, PCR protocols. a guide to methods and applications $18,315-322$.

Zhang ZF, Liu F, Zhou X, Liu XZ et al. 2017 - Culturable mycobiota from Karst caves in China, with descriptions of 20 new species. Persoonia 39, 1-31. 